\title{
A TEORIA DA DESCONSIDERAÇÃO DA PERSONALIDADE JURÍDICA E A RESPONSABILIDADE DOS SÓCIOS NO PROCESSO FALIMENTAR
}

Fabrício Pinto Weiblen ${ }^{1}$

\begin{abstract}
RESUMO: O presente estudo se propõe a analisar questões referentes à desconsideração da personalidade jurídica como meio de coibir fraudes possibilitadas pelo uso indevido da autonomia patrimonial da pessoa jurídica, assim como, a partir da Lei 11.101/05, apresentar reflexões acerca da responsabilidade dos sócios na hipótese de processo falimentar envolvendo sociedades empresárias. Desse modo, estuda de forma conjunta a possibilidade de as obrigações da sociedade falida atingirem o patrimônio particular de seus sócios, e as inovações legislativas acerca da disregard doctrine no Direito brasileiro, bem como as críticas apontadas pela doutrina nacional.

PALAVRAS-CHAVE: desconsideração da personalidade jurídica, processo falimentar, responsabilidade societária, disregard doctrine.
\end{abstract}

\section{The disregard of legal entity doctrine and the associates' responsibility in the bankrupt process.}

ABSTRACT: The present study proposes itself to analyze questions that refer to the disregard of legal entity doctrine as a way to cohibit frauds allowed by the improper use of the patrimonial autonomy of the legal entity, as well as, through the Law 11.101/05, present reflections about the associates' responsibility in the hypothesis of bankrupt process involving commercial associations. This way, it studies in a unite form the possibility of the obligations from the bankrupt association to reach its associates' private patrimony, and the legislative innovations about the disregard doctrine in the Brazilian Law, as well as the critiques pointed by the national doctrine.

KEY-WORDS: disregard of legal entity, bankrupt process, associate's responsibility, disregard doctrine.

\section{INTRODUÇÃO}

Com o decorrer do tempo, a sociedade tende a evoluir de forma rápida e, à medida que surgem novas relações entre as pessoas, surgem também novos impasses, de modo que há uma busca pela prestação jurisdicional correspondente. Assim, a necessidade de adequação à nova realidade leva a que o ordenamento jurídico crie instrumentos que visam a proteger as relações sociais originadas.

A exemplo das conseqüências da evolução social, a sociedade empresária, atualmente, tem fundamental papel na econômia mundial, porquanto gera empregos, paga tributos e propicia o surgimento de diversos negócios paralelos que vêm a contribuir para o crescimento da região em que está instalada. Desse modo, a fim de

\footnotetext{
${ }^{1}$ Acadêmico do Curso de Direito da UFSM. E-mail: fabriciopw@terra.com.br.

(C) 2008. Departamento de Direito da UFSM. Todos os direitos reservados.
} 
estimular o empreendedorismo e auxiliar no crescimento dessas sociedades empresárias, foi criado o princípio da autonomia patrimonial, possibilitado pela pessoa jurídica.

Contudo, a partir do surgimento de uma nova realidade e das conseqüentes criações com o intuito de atingir um novo equilíbrio, surgem também novas possibilidades de fraudes e uso indevido, de forma que novos impasses são originados. Com o instituto da pessoa jurídica não foi diferente. A partir de sua criação, seu principal objetivo, qual seja, separar a pessoa do sócio e da sociedade, foi sendo utilizado como meio para fraudes e enriquecimento ilícito.

Além disso, principalmente na hipótese de sociedade cuja falência foi decretada, freqüentemente não ocorre o pagamento de seus credores, muitas vezes em decorrência do referido princípio da autonomia patrimonial.

Dessa forma, a pessoa jurídica teve sua finalidade desviada e, como solução, criou-se a teoria da desconsideração da personalidade jurídica, de modo a estabelecer o equilíbrio através da responsabilização do causador do ilícito, atribuindo a determinado indivíduo o dever de restabelecimento ou compensação. Nesse diapasão, determinadas questões vêm à tona, tais como: Quais são os reflexos da teoria da desconsideração da personalidade jurídica no ordenamento jurídico brasileiro? Que critérios utilizar para sua aplicação? Que nível de responsabilidade têm os sócios de sociedade falida? Como se dá a incidência da desconsideração na sociedade falida?

Diante disso, o presente estudo tem por escopo fazer uma análise do impasse entre o princípio da autonomia patrimonial e a teoria da desconsideração da personalidade jurídica, bem como tratar acerca de sua aplicação no processo falimentar e, principalmente, na sociedade empresária falida. Para tanto, o artigo será dividido em cinco partes. Primeiramente, será feita uma abordagem dos aspectos referentes à personalidade jurídica das sociedades empresárias. Em um segundo momento, serão analisados alguns apontamentos sobre o surgimento e os reflexos da teoria da desconsideração da personalidade jurídica no ordenamento jurídico brasileiro. Então, serão traçadas algumas considerações acerca da responsabilidade dos sócios no processo falimentar. Em seguida, far-se-á um estudo sobre a possibilidade da incidência de tal teoria na sociedade falida e, por fim, tentar-se-á trazer algumas breves considerações finais, bem como perspectivas acerca da matéria.

\section{PERSONALIDADE JURÍDICA NAS SOCIEDADES EMPRESÁRIAS}


O ser humano, pessoa física ou natural, é possuidor de capacidade jurídica. Contudo, não é capaz de realizar grandes empreendimentos, se considerado isoladamente. Assim, tornou-se clara a necessidade de união, conjugação de esforços, de modo a possibilitar a realização de tais empreendimentos, através da reunião de atividades em torno de um grupo.

Dessa forma, necessária se faz a atribuição de capacidade jurídica, ou seja, personalizar entes abstratos gerados pela vontade e necessidade do homem. As pessoas jurídicas surgem, portanto, ora como conjunto de pessoas, ora como destinação patrimonial, com aptidão para adquirir direitos e contrair obrigações. (VENOSA, 2005, p.255). Noutras palavras, a referida personalização tem o sentido de autorizar determinados sujeitos de direito à prática de atos jurídicos em geral.

Daí se depreende que podem existir sujeitos de direito despersonalizados e personalizados. Acerca dessa distinção, Fábio Ulhoa Coelho (2006) traz lição esclarecedora:

O que distingue o sujeito de direito despersonalizado do personalizado é o regime jurídico a que ele stá submetido, em termos de autorização genérica para a prática de atos jurídicos. Enquanto as pessoas estão autorizadas a praticar todos os atos jurídicos a que não estejam expressamente proibidas, os sujeitos de direito despersonalizados só poderão praticar os atos a que estejam, explicitamente, autorizados pelo direito. (COELHO, 2006, p.112).

A Lei 11.101, de 9 de fevereiro de 2005, chamada Lei de falências e de recuperação de empresas, conforme seu art. $1^{\circ}$, “disciplina a recuperação judicial, a recuperação extrajudicial e a falência do empresário e da sociedade empresária”. Ou seja, a referida legislação regula matéria aplicável tão-somente ao empresário individual e à sociedade empresária.

No concernente à personalidade dos atingidos pela Lei de falências, o empresário individual é pessoa física ${ }^{2}$, enquanto a sociedade empresária é pessoa jurídica. Consoante o Código Civil, a sociedade empresária, objeto do presente estudo, conceituada como a pessoa jurídica de direito privado não-estatal, que explora empresarialmente seu objeto social ou a forma de sociedade por ações (COELHO, 2006,

\footnotetext{
${ }^{2} \mathrm{O}$ empresário individual é considerado pessoa jurídica para fins tributários.

(C) 2008. Departamento de Direito da UFSM. Todos os direitos reservados.
} 
p.111), faz parte dos sujeito de direito personalizados ${ }^{3}$ e, portanto, tem capacidade para praticar qualquer ato ou negócio jurídico em relação ao qual inexista proibição expressa.

Daí decorrem três principais conseqüências aplicáveis às sociedades empresárias, quais sejam, a titularidade processual, que consiste na capacidade da sociedade empresária de ser parte processual, ou seja, capacidade de demandar e ser demandada em juízo; a titularidade negocial, que torna a sociedade parte de um negócio jurídico realizado por ela, não obstante isto ter ocorrido por intermédio de um representante; e a responsabilidade patrimonial, que tem como efeito a incomunicabilidade entre o patrimônio da sociedade e o patrimônio de seus sócios, que, via de regra, não responderão pelas obrigações assumidas pela sociedade.

Esta última conseqüência da personalização da sociedade empresária, particularmente, interessa à presente análise, na medida que, em determinadas hipóteses, o patrimônio dos sócios poderá ser atingido em decorrência de dívidas da sociedade, como será examinado posteriormente.

\section{A TEORIA DA DESCONSIDERAÇÃO DA PERSONALIDADE JURÍDICA}

A pessoa jurídica, como atributo que o Estado defere a determinados entes, foi criada para alcançar fins sociais necessariamente lícitos. Nesse sentido estabelece a Consituição Federal, em seu art. 5, XVII: "é plena a liberdade de associação para fins lícitos, vedada a de caráter paramilitar".

Contudo, a despeito da previsão legal, a autonomia patrimonial da pessoa jurídica é utilizada amiúde como instrumento para atos ilícitos, abusivos ou fraudulentos por parte dos sócios, de modo atingir fins escusos ou prejudicar terceiros ${ }^{4}$.

\subsection{Breve histórico}

Nesse quadro, não demorou a surgir posição doutrinária e jurisprudencial a respeito, com o escopo de coibir tais atos, que vão de encontro aos fins sociais almejados pela figura da pessoa jurídica. A partir de tais posturas, emergiu a teoria da

\footnotetext{
${ }^{3}$ Art. 44, II CC.

${ }^{4}$ De fato, Rubens Requião (2007, p.390) afirma que a teoria da personalidade jurídica, aplicada às sociedades comerciais, não deixa de criar sérios problemas, chegando ao ponto de o autor pressentir sua decadência.
} 
desconsideração da personalidade jurídica no exterior, a qual, posteriormente, veio a ser adotada pelo direito brasileiro.

\subsubsection{Origem no direito alienígena}

A disregard doctrine, como é conhecida a teoria da desconsideração da personalidade jurídica, apresenta divergências quanto à sua origem, ou seja, há diversos juízos acerca de qual seria o evento no qual ocorreram as primeiras referências ou aplicações da referida teoria. O célebre caso Salomon vs. Salomon \& Co. é usualmente apontado pela doutrina como um dos pioneiros. Este pronunciamento da Corte de justiça da Inglaterra, julgado em 1897, é mencionado na monografia "Il Superamento della Personalità Giuridica delle Società di Capitali" de Piero Verrucoli, da Universidade de Pisa, e citado por Rubens Requião (2007, p.392). Nesta apreciação realizada pela justiça inglesa, ficou claramente demonstrado que Aaron Salomon detinha o total controle societário sobre a própria personalidade da sociedade, justificando, portanto, a desconsideração da personalidade jurídica (ALMEIDA, 2001, p. 184).

Amador Paes de Almeida (2001, p.184) anota, ainda, que Suzy Elizabeth Cavalcante Koury, em sua obra "A desconsideração da personalidade jurídica (disregard doctrine) e os grupos de empresas", 2. ed. Forense: 1995, p. 64, noticia como sendo o primeiro caso de aplicação do instituto o Bank of United States vs. Deveaux, julgado nos Estados Unidos em 1809.

\subsubsection{Adoção pelo direito pátrio}

Alguns autores, tais como Elizabeth Cristina de Freitas (2002, p.274) e Amador Paes de Almeida (2001, p.184), citam a legislação trabalhista como pioneira na doutrina da desconsideração, apontando o art. $2^{\circ}, \S 2^{\circ}$, da Consolidação das Leis do Trabalho ${ }^{5}$, de 1943, como exemplo de aplicação do instituto.

Todavia, parte da doutrina assinala que a teoria da desconsideração somente foi inserida no ordenamento jurídico brasileiro com o advento do Código de Defesa do

\footnotetext{
5 "Sempre que uma ou mais empresas, tendo, embora, cada uma delas, personalidade jurídica própria, estiverem sob a direção, controle ou administração de outra, constituindo grupo industrial, comercial ou de qualquer outra atividade econômica, serão, para os efeitos da relação de emprego, solidariamente responsáveis a empresa principal e cada uma das subordinadas”.
}

(C) 2008. Departamento de Direito da UFSM. Todos os direitos reservados. 
Consumidor, particularmente em seu art. $28^{6}$ (COELHO, 2002, p.49). Para esta parcela da doutrina, as previsões anteriores ao CDC configuram meras atribuições de responsabilidade solidária, as quais não podem ser entendidas como forma de aplicação da doutrina da desconsideração da personalidade jurídica, muito embora possam, às vezes, ter os mesmos objetivos.

\subsection{Reflexos no ordenamento jurídico brasileiro}

Nesse contexto, cada vez mais ganha corpo na doutrina e legislação brasileiras a mitigação do princípio da autonomia patrimonial da pessoa jurídica. Tal abrandamento é justificado pelo fato de que, sob determinadas circunstâncias, não é possível sustentar a distinção entre pessoa jurídica e pessoa natural, visto que há situações nas quais preservar a proteção à pessoa jurídica leva a profundas distorções e iniqüidades.

Portanto, quando a personalidade jurídica servir de meio para fugir a sua finalidade, para lesar terceiros, deve ser desconsiderada, decidindo o julgador como se o ato ou negócio houvesse sido praticado pela pessoa natural (ou outra pessoa jurídica). Daí decorre que não se trata de se reputar nula a pessoa jurídica, mas sim, em determinadas hipóteses, não a levar em consideração ${ }^{7}$. Tal não implica, via de regra, em negar validade à existência da pessoa jurídica (VENOSA, 2005, p.313).

Com efeito, à medida que a teoria da desconsideração evoluiu no ordenamento brasileiro, pôde-se perceber sua inserção em diversos dispositivos legais, evidentemente, de formas distintas, cada uma com suas peculiaridades. Assim, tais especificidades devem ser abordadas, ainda que de forma breve.

\subsubsection{Código de Defesa do Consumidor (Lei 8.078/90)}

Como já assinalado, o CDC é tido por muitos como o pioneiro na aplicação da disregard of legal entity no direito brasileiro. Tal aplicação é evidenciada em seu art. 28, in verbis:

\footnotetext{
6 "O juiz poderá desconsiderar a personalidade jurídica da sociedade quando, em detrimento do consumidor, houver abuso de direito, excesso de poder, infração da lei, fato ou ato ilícito ou violação dos estatutos ou contrato social. A desconsideração também será efetivada quando houver falência, estado de insolvência, encerramento ou inatividade da pessoa jurídica provocados por má administração".

${ }^{7}$ Nesse sentido, consoante salienta Rubens Requião (2007, p.393) o foco da doutrina é o de demonstrar que a personalidade jurídica não constitui um direito absoluto, mas está sujeita e contida pela teoria da fraude contra credores e pela teoria do abuso de direito, tema abordado pelo autor em "Abuso de direito e fraude atavés da personalidade jurídica" (Revista dos Tribunais, 410/12).
} 
Art. 28. O juiz poderá desconsiderar a personalidade jurídica da sociedade quando, em detrimento do consumidor, houver abuso de direito, excesso de poder, infração da lei, fato ou ato ilícito ou violação dos estatutos ou contrato social. A desconsideração também será efetivada quando houver falência, estado de insolvência, encerramento ou inatividade da pessoa jurídica provocados por má administração.

$\S 1 .^{\circ}$ (vetado)

$\S 2 .^{\circ}$ As sociedades integrantes dos grupos societários e as sociedades controladas, são subsidiariamente responsáveis pelas obrigações decorrentes deste Código.

$\S 3 .^{\circ}$ As sociedades consorciadas são solidariamente responsáveis pelas obrigações decorrentes deste Código.

$\S 4 .^{\circ}$ As sociedades coligadas só respondem por culpa.

$\S 5 .^{\circ}$ Também poderá ser desconsiderada a pessoa jurídica sempre que sua personalidade for, de alguma forma, obstáculo ao ressarcimento de prejuízos causados aos consumidores.

No que diz respeito a tal dispositivo, apenas a primeira parte de seu caput se aproxima da formulação original da doutrina da desconsideração, tendo em vista a utilização abusiva da pessoa jurídica, acrescentando, porém, o elemento "em detrimento do consumidor" como requisito para tanto (FREITAS, 2002, p.172). Em relação aos parágrafos $2 .^{\circ}, 3 .^{\circ}$ e $4 .^{\circ}$, importante ressaltar que não versam sobre desconsideração da personalidade jurídica, mas simplesmente de responsabilidade em sentido lato (FREITAS, 2002, p.204).

Quanto ao $\S 5^{\circ}$, freqüentemente criticado, cumpre destacar que não pode ser interpretado com amplitude tal que torne letra morta o caput, pois estariam feridos os pressupostos teóricos da desconsideração, haja vista que exige apenas a existência de prejuízos ao consumidor não indenizados pela pessoa jurídica, indo de encontro ao princípio da autonomia patrimonial (COELHO, 2002, p.52).. Ademais, há o entendimento de que o veto do $\S 1^{\circ}$ deveria ter sido direcionado ao $\S 5^{\circ}$, como elucida Zelmo Denari (2007):

De sua [das razões de veto encaminhadas ao presidente do Senado Federal] leitura se infere que, por um equívoco remissivo, o veto recaiu sobre o $\$ 1^{o 8}$ quando, de modo coerente, deveria versar seu $\$ 5^{\circ}$, que -com excessivo rigor e desprezando os pressupostos da fraude e do abuso de direito previstos no caput

\footnotetext{
${ }^{8}$ Nas razões do veto, o presidente da República considerou que "o caput do art. 28 já contém todos os elementos necessários à aplicação da desconsideração da personalidade jurídica, que constitui, conforme doutrina amplamente dominante no Direito pátrio e alienígena, técnica excepcional de repressão a práticas abusivas". Nota-se que não há relação alguma entre as razões de veto e o disposto no parágrafo $1^{\circ}$, que versa tão-somente acerca da legitimidade passiva na hipótese de acolhimento da desconsideração da personalidade jurídica. Por outro lado, seria justificativa adequada para eventual veto do $\S 5^{\circ}$.
}

(C) 2008. Departamento de Direito da UFSM. Todos os direitos reservados. 
do art.28 - desconsidera a pessoa jurídica 'sempre que sua personalidade for, de alguma forma, obstáculo ao ressarcimento de prejuízos causados aos consumidores' (DENARI et al., 2007, p.248)

Assim, não se pode deixar de reconhecer o comprometimento da eficácia deste parágrafo no plano das relações de consumo. Por fim, Elizabeth Cristina de Freitas (2002, p.207), refere que esse dispositivo deve ser interpretado juntamente com o caput do art. 28, de modo que só será autorizada a desconsideração se presentes os requisitos deste.

\subsubsection{Lei Antitruste (Lei 8.884/94)}

Posteriormente ao Código de Defesa do Consumidor, a Lei 8.884/94 tornou a versar sobre má administração e desconsideração da personalidade jurídica, mormente em seu art. 18, senão vejamos:

Art. 18. A personalidade jurídica do responsável por infração da ordem econômica poderá ser desconsiderada quando houver por parte deste abuso de direito, excesso de poder, infração da lei, fato ou ato ilícito ou violação dos estatutos ou contrato social. A desconsideração também será efetivada quando houver falência, estado de insolvência, encerramento ou inatividade da pessoa jurídica provocados por má administração.

Da leitura de tal dispositivo infere-se que há clara semelhança com o teor do art. 28 do CDC, já abordado. Com efeito, a partir de tal similaridade, o art. 18 da Lei 8.884/94 tem recebido as mesmas críticas, uma vez que igualmente inclui casos que não se confundem com a disregard doctrine, como na hipótese de encerramento da empresa por má administração (COELHO, 2002, p.53).

Em verdade, a norma sob exame pode ser vista como reflexo do estabelecido no art. $173, \S 5^{\circ}$ da Consituição Federal, qual seja, a responsabilização da pessoa jurídica, bem como de seus membros, por atos praticados contra a ordem econômica e financeira e contra a economia popular.

\subsubsection{Lei do Meio Ambiente (Lei 9.605/98)}

A Lei 9.605/98, que dispões acerca das sanções administrativas e penais decorrentes de condutas e atividades lesivas ao meio ambiente, por sua vez, prevê, em seu art. $4^{\circ}$, que: 
Art. 4. ${ }^{\circ}$ Poderá ser desconsiderada a pessoa jurídica sempre que sua personalidade for obstáculo ao ressarcimento de prejuízos causados à qualidade do meio ambiente.

No tocante a este artigo, deve-se atentar para o fato de que, não obstante esteja expressamente permitida a desconsideração da personalidade jurídica, uma breve análise de sua redação leva à conclusão de que a referida permissão não se sujeita aos requisitos da disregard doctrine, em sua proposta original. Noutras palavras, pelo estabelecido no dispositivo legal em comento, será suficiente que haja um dano e, findo o patrimônio da pessoa jurídica, não for possível alcançar os bens dos sócios em razão do princípio da autonomial patrimonial, para que seja aplicável a desconsideração da pessoa jurídica, uma vez que esta situação efetivamente configura obstáculo ao ressarcimento causado pela personalidade jurídica.

Por outro lado, existe o posicionamente doutrinário de que a simples insuficiência de bens para ressarcimento de danos ao meio ambiente não seria o bastante para autorizar a desconsideração. Segunda esta corrente, o art. $4^{\circ}$ da Lei 9.605/98 deve ser interpretado conforme a formulação original da teoria da desconsideração da personalidade jurídica, tornando-se imprescindível, dessa forma, a caracterização de utilização indevida da pessoa jurídica para que sejam aplicadas suas conseqüências (COELHO, 2002, p.53).

\subsubsection{Código Civil (Lei 20.406/02)}

Finalmente, a teoria da desconsideração foi inserida no Código Civil de 2002, de modo a consolidar sua recepção pelo ordenamento brasileiro de forma substancial. Assim, em seu art. 50, o Novo Codex Civil estatui que:

Art. 50. Em caso de abuso da personalidade jurídica, caracterizado pelo desvio de finalidade, ou pela confusão patrimonial, pode o juiz decidir, a requerimento da parte, ou do Ministério Público quando lhe couber intervir no processo, que os efeitos de certas e determinadas relações de obrigações sejam estendidos aos bens particulares dos administradores ou sócios da pessoa jurídica.

Tal previsão no Código Civil, na medida que poderá ser aplicada às sociedades empresárias, é aquela que mais interessa à presente análise, muito embora o 
estabelecido no referido artigo não diferir em grande parte da formulação teórica da disregard of legal entity.

Da leitura do dispositivo supracitado, infere-se que o abuso da personalidade jurídica se configura pela presença do desvio de finalidade ou da confusão patrimonial. Assim, o texto legal restou muito mais simplificado, objetivo e prático em face da redação do art. 28 do $\mathrm{CDC}$, de modo que o abuso em decorrência do desvio de finalidade, previsto no art. 50 do CC, abarca, na prática, todas as hipóteses previstas na Lei consumerista Pinto, 2003, p. 77-78).

Assim, a aplicação do previsto no Código Civil consiste em ignorar a personalidade jurídica autônoma da entidade moral sempre que esta venha a ser utilizada para fins fraudulentos ou diversos daqueles para os quais foi constituída, permitindo que o credor de obrigação assumida pela pessoa jurídica alcance o patrimônio particular dos seus sócios ou administradores para a satisfação de seu crédito (NERY JR., 2006, p.208).

Importante salientar que, ao contrário da Lei de Proteção ao Meio Ambiente (Lei 9.605/98), aqui é pacífico o entendimento da necessidade da má utilização da pessoa jurídica, ou seu uso como expediente para a realização de fraude para a aplicação do dispositivo. Nesse sentido, preleciona Fabio Ulhoa Coelho (2006):

Pressuposto inafastável da despersonalização episódica da pessoa jurídica, no entanto, é a ocorrência de fraude por meio da separação patrimonial. Não é suficiente a simples insolvência do ente coletivo, hipótese em que, não tendo havido fraude na utilização da separação patrimonial, as regras de limitação da repsonsabilidade dos sócios terão ampla vigência. A desconsideração é instrumento de coibição do mau uso da pessoa jurídica; pressupõe, portanto, o mau uso. $O$ credor da sociedade que pretende a sua desconsideração deverá fazer prova da fraude perpetrada, caso contrário suportará o dano da insolvência da devedora. Se a autonomia patrimonial não foi utilizada indevidamente, não há fundamento para a sua desconsideração (COELHO, 2006, p. 126).

Nessa esteira, o art. 50 do $\mathrm{CC}$ trata de diversas hipóteses que ensejariam a desconsideração da personalidade jurídica, tais como, abuso de direito, fraude, desvio de finalidade e confusão patrimonial.

Ainda, imperioso acrescentar, sobre os efeitos e consequiências da desconsideração, que tal teoria não atinge a validade do ato constitutivo, mas tãosomente a sua eficácia episódica. Desse modo, uma sociedade que tenha a autonomia

(C) 2008. Departamento de Direito da UFSM. Todos os direitos reservados. 
patrimonial desconsiderada continua válida, assim como válidos permanecem todos os demais atos que realizou. Daí decorre a grande vantagem da disregard doctrine em relação a outros mecanismos de coibição da fraude, tais como anulação ou dissolução da sociedade. A teoria da desconsideração preserva a empresa, que não será necessariamente atingida por ato fraudulento de um de seus sócios, tendo em vista que apenas suspende a eficácia do ato constitutivo, no episódio sobre o qual recai o julgamento, sem invalidá-lo. Nesse quadro, resguardam-se os demais interesses que gravitam ao seu redor, como os dos empregados, dos demais sócios, da comunidade etc. (COELHO, 2006, p.127).

Por fim, não se pode olvidar da possibilidade de a desconsideração incidir também para responsabilizar a pessoa jurídica por atos de seus membros ou sócios, e não somente para responsabilizar os sócios, hipótese denominada por Eduardo Viana Pinto (2003, p.73) como desconsideração da pessoa jurídica ao inverso ${ }^{9}$.

\section{RESPONSABILIDADE DOS SÓCIOS NO PROCESSO FALIMENTAR}

Como visto, a pessoa jurídica consiste em uma atribuição de personalidade a determinado ente, ou seja, a certos entes abstratos é dada a prerrogativa de ter capacidade jurídica. Trazendo esse contexto para a sociedade falida, chega-se à conclusão de que o falido sofre uma limitação em sua capacidade jurídica no que diz respeito ao direito de propriedade. Em outras palavras, a partir da decretação da falência, o devedor é privado do direito de administrar e dispor de seu patrimônio. Não perde a propriedade de seus bens, senão após a liquidação (COELHO, 2006, p. 341).

Partindo-se dessa premissa, mister analisar as possibilidades de responsabilização dos sócios da sociedade falida, conforme a legislação societária, bem como, por óbvio, a nova Lei de Falências (Lei 11.101/05). Para tanto, e com o intuito de facilitar a compreensão, será feita uma separação, conforme a realizada na referida Lei, em sociedades de responsabilidade ilimitada e limitada.

\footnotetext{
${ }^{9}$ O autor exemplifica tal ocorrência com um caso em que determinado devedor adquire um imóvel, através de um contrato de promessa de compra e venda, quitando o seu valor, através de parcelamento. Ao final, lavra a escritura pública de compra e venda em nome da pessoa jurídica, da qual é sócio ou acionista majoritário, valendo-se de cláusula que lhe permite seja esse ato traslativo celebrado a seu favor ou em nome de quem possa vir a indicar. Transfere seu patrimônio para a pessoa jurídica para resguardar seus bens quando da responsabilização pelas suas dívidas, afastando-os de constrição judicial.
}

(C) 2008. Departamento de Direito da UFSM. Todos os direitos reservados. 


\subsection{Sociedade com responsabilidade ilimitada}

A responsabilização dos sócios das sociedades com responsabilidade ilimitada é é disciplinada no art. 81 da Lei 11.101/05. Por esse regramento, os sócios dos tipos societários abrangidos pela responsabilidade ilimitada terão sua falência decretada junto com a da sociedade. Ou seja, o regime atual determina a falência do sócio com responsabilidade ilimitada no caso da empresa entrar em regime de insolvência. De fato, o dispositivo legal supracitado impõe a citação de tais sócios para contestar o pedido de falência. Assim, decretada a falência, o sócio compreendido na hipótes ora tratada estará sujeito aos efeitos jurídicos produzidos em relação à sociedade falida.

Forçoso apontar que, dessa forma, a lei estabelece nesses casos a possibilidade de falência de quem não tem necessariamente a qualidade de empresário, logo, apresenta uma exceção ao art. $1^{\circ}$ da mesma lei, o qual estatui que a falência se limita ao empresário individual e à sociedade empresária.

Será também atingido pelos efeitos da falência o sócio com responsabilidade ilimitada que se tenha retirado voluntariamente ou tenha sido excluído por deliberação dos demais (art. 1030 do Código Civil), há menos de dois anos da decisão que decretar a falência (art. 81, § 1o da Lei no. 11.101/05). Tais efeitos, entretanto, se limitam às obrigações existentes na data do arquivamento da alteração contratual que implicou na retirada do sócio, e que ainda subsistam na ocasião da decretação da falência. Na hipótese de a retirada do sócio ter ocorrido há mais de dois anos, a contar da data da declaração da falência, o mesmo não será alcançado pelo efeito descrito. Não o será também, para os efeitos da falência, o sócio excluído, há qualquer tempo, por ordem judicial, haja vista a menção à "data do arquivamento da alteração do contrato", da qual se presume que a retirada por decisão judicial isenta o excluído dos efeitos do art. 81 , § $1^{\circ}$.

Todavia, no dizer de Fábio Ulhoa Coelho (2007, p.205), há uma falta de implicação prática relevante no art. 81, a qual reside no âmbito de incidência do preceito, haja vista que a responsabilização ilimitada dos sócios abrangem tão-somente as sociedades em nome coletivo, comandita simples (em relação ao comanditado) e por ações (em relação ao acionista-diretor). Tais tipos societários são raramente utilizados hoje em dia, logo, segundo o autor, a profunda alteração que o dispositivo introduz acaba se limitando ao aspecto conceitual da questão. 


\subsection{Sociedade com responsabilidade limitada}

De outra banda, o limite da responsabilização dos sócios nas sociedades de responsabilidade limitada falidas é disciplinado pelo art. 82 da Lei 11.101/05. Este preceito traz tratamento bastante diferente daquele previsto pelo Decreto-Lei 7.661/45, a antiga Lei de Falências, começando por não distinguir a sociedade de pessoas da sociedade de capitais, para aquele efeito. Logo, o dispositivo abarca tanto as sociedades limitadas como as sociedades anônimas.. Além disso, o sócio ou acionista, ou aquele que tenha deixado esta condição, terá sua responsabilidade pessoal apurada independentemente de integrar ou não a sociedade ou sua administração na ocasião da falência ${ }^{10}$.

No tocante à responsabilidade dos sócios da sociedade limitada, tal pode ocorrer em duas hipóteses, sendo que em ambas, no regime falimentar, terão a guarida do art. 82 na procura da responsabilidade do sócio. Na primeira, quando participar de deliberação social infringente da lei ou do contrato social (art. 1.080 do CC), configurando caso de responsabilidade por ato ilícito, em que não há nenhuma limitação. Enquanto o patrimônio do sócio responsável pelo ilícito suportar, pode-se cobrar dele a indenização pelo prejuízo. Na segunda, o sócio responde solidariamente com os demais pela integralização do capital social (art. 1052 do CC). Aqui, a responsabilidade independe de ilícito, porém, limita-se ao total do capital social subscrito e não integralizado. Este consiste no montante de recursos que os sócios se comprometem a entregar para a formação da sociedade, enquanto aquele é tido como a parte do capital social que eles efetivamente entregam. Como conseqüência, se o contrato social estabelece que o capital está totalmente integralizado, os sócios não têm nenhuma responsabilidade pelas obrigações sociais, uma vez que sua responsabilidade solidária se restringe à integralização do capital social. Portanto, falindo a sociedade, e sendo insuficiente o patrimônio social para a liquidação do passivo, a perda será suportada pelos credores. (COELHO, 2006, pp.156-157). Caso contrário, se o contrato social contempla cláusula estabelecendo que o capital subscrito ainda não está totalmente integralizado, a massa falida pode demandar a integralização de qualquer um dos sócios, através da chamada ação de integralização.

\footnotetext{
10 Aqui, a lei não estabelece limite de tempo, dentro do qual o ato praticado possa gerar a responsabilidade descrita. Contudo, a ação de responsabilização, forte no art. $82, \S 2^{\circ}$, prescreve no prazo de dois anos, a contar da sentença de encerramento da falência.
}

(C) 2008. Departamento de Direito da UFSM. Todos os direitos reservados. 
Cabe, outrossim, tecer breves considerações sobre os controladores e administradores, também contemplados pelo dispositivo falencial. Do mesmo modo que os sócios, deverão ter sua responsabilidade pessoal, pelos atos que infringiram a lei, o contrato ou estatuto, apurada pelo juízo falimentar.

$\mathrm{O}$ acionista controlador tem responsabilidade pelos danos que decorrerem de abuso no exercício do poder de controle, segundo o art. 117 da Lei 6.404/76, Lei das Sociedades Anônimas. Trata-se de abuso de direito, que, consoante o art. 187 do Código Civil, é qualificado como ato ilícito. Ademais, o acionista, controlador ou não, inobstante o dispositivo mencionar apenas o controlador, também responde pela integralização do capital da sociedade anônima, podendo ser compelido judicialmente a cumprir sua obrigação nos termos da lei própria e do art. 82 da Lei 11.101/05, por meio da já referida ação de integralização.

Nesse diapasão, importante ressaltar que o conceito de controlador da sociedade pode ser utilizado na sociedade de responsabilidade limitada, pois a ela podem ser aplicadas, subsidiariamente, normas da sociedade por ações. Ainda, deve-se apontar que o administrador, na sociedade de responsabilidade limitada, responde quando descumprir o dever de diligência e prejudicar, com isso, a sociedade, ou cometer ato ilícito no exercício da gerência dos negócios sociais (art. 1.011 do CC e art. 158 da Lei 6.404/76). A responsabilização não está sujeita à decretação da falência da sociedade, podendo ocorrer mesmo na ausência de tal decretação, entretanto, para que ocorra, imprescindível ficar caracterizada a conduta dolosa ou culposa, ou a violação da lei ou estatuto, consoante o art. 158 da Lei das Sociedades Anônimas.

Finalmente, insta atentar para o fato de que a responsabilidade pessoal dos sócios, acionistas, controladores e administradores, nos termos das normas acima descritas, será sempre subjetiva. Daí decorre a origem da norma do art. 82 da Lei de falência, porquanto sendo subjetiva, a responsabilidade terá que ser definida, dimensionada, conforme expressa a lei (COELHO, 2007, pp.208-209).

\section{A TEORIA DA DESCONSIDERAÇÃO E A SOCIEDADE FALIDA}

Do exposto, pode-se inferir que um dos papéis principais do processo falimentar se deve ao fato de se buscar o afastamento do sócio incompetente e, ao mesmo tempo, permitir a manutenção da atividade empresarial. Nessas situações, como visto retro, o

(C) 2008. Departamento de Direito da UFSM. Todos os direitos reservados. 
alcance do patrimônio particular se restringe a uma forma subsidiária, e mais, é limitado também de acordo com capital investido, quotas adquiridas não integralizadas, tipo de empresa em que participa e a sua função dentro dela.

Assim, apenas após a análise destes fatores pode ser apurada a responsabilidade dos sócios. A partir de tais determinantes, fica evidenciada a dificuldade de pagamento dos credores da sociedade falida, sendo que é improvável que todos os credores tenham seus créditos satisfeitos ${ }^{11}$, muito embora geralmente a falência da sociedade empresária se deva à sua má administração.

Desta feita, seguindo os princípios e pressupostos da incidência da teoria da desconsideração da personalidade jurídica, mormente aqueles estabelecidos pelo art. 50 do Código Civil, cabível sua aplicação na sociedade falida, de modo a tornar a responsabilidade dos sócios pessoal, para que os bens que integram seu patrimônio particular sejam atingidos para o pagamento das obrigações; direta, com o intuito de não haver necessidade do esgotamento do patrimônio da pessoa jurídica para que se passe ao dos sócios; e ilimitada, de forma que a responsabilidade não fique vinculada a limites de integralização de quotas ou ações subscritas ou adquiridas, tampouco a tipos societários.

Com efeito, a falência e até mesmo o estado de insolvência ou inatividade da pessoa jurídica são, também, causas que permitem a decretação da superação da autonomia patrimonial, porém condicionada a que esse evento societário tenha sido provocado por má gestão, cuja prova incumbe ao credor, sob pena de insucesso da demanda.

Ademais, não se pode olvidar do regramento presente no art. 18 da Lei 8.884/94, referido no item 3.2.2, o qual traz expressamente a possibilidade de aplicação da desconsideração quando houver falência da pessoa jurídica provocada por má administração. Assim, uma vez comprovada tal ocorrência, o que se dá em grande parte dos casos, deve-se desconsiderar a autonomia patrimonial, de modo a atingir os bens dos sócios.

Esse comprovação, cuja prova compete ao interessado e que deve ser produzida de maneira completa e convincente, usualmente se constitui em encargo de difícil execução, muitas vezes inatingível. Entretanto, em alguns casos a situação se abranda, tendo em vista que pelo art. $6^{\circ}$, VIII, do CDC, está expressamente assegurada a inversão

\footnotetext{
${ }^{11}$ Sobressai-se o caso dos credores quirografários, que, pela classificação de seu crédito na ordem do art. 83 da Lei de Falências, comumente não têm seus créditos satisfeitos.
}

(C) 2008. Departamento de Direito da UFSM. Todos os direitos reservados. 
do ônus probatório em prol da figura do consumidor. Assim, nas relações consumeristas, basta ao consumidor produzir verossímil alegação, ou ser hipossuficiente, para que seja acolhido esse pleito, mas sempre a critério da autoridade judicante. Ainda, em se tratando de falência, a produção da prova por má administração se torna mais facilitada, porque o Ministério Publico e o Banco Central registram todos os passos da soceidade falida e estão em condições de fornecer informações detalhadas a respeito de possíveis fraudes ou da prática de qualquer outro procedimento ilícito. (PINTO, 2003, p. 33).

Desse modo, não restam dúvidas quanto à possibilidade da aplicação da desconsideração na sociedade falida, bem como da ampla previsão legal de tal ocorrência.

No entanto, imperioso frisar que a legislação societária traz dispositivos que, a despeito de representarem um embrião da superação da personalidade jurídica da sociedade, não podem ser vistos como real aplicação da disregard doctrine, se analisada sua formulação teórica. Entre esses regramentos, podemos citar o art. 596 do Código de Processo Civil, que estabalece que:

Art. 596. Os bens particulares dos sócios não respondem pelas dívidas da sociedade senão nos casos previstos em lei; o sócio, demandado pelo pagamento da dívida, tem direito a exigir que sejam primero excutidos os bens da sociedade.

Outro exemplo seria o já citado art. 158, da Lei das Sociedades Anônimas (Lei 6.404/76), que da mesma forma estatui:

Art. 158. O administrador não é pessoalmente responsável pelas obrigações que contrair em nome da sociedade e em virtude de ato regular gestão; responde, porém civilmente, pelos prejuízos que causar, quando proceder:

I-dentro de suas atribuições ou poderes, com culpa ou dolo;

II - com violação da lei ou do estatuto.

Da leitura de tais normas, como elucida Amador Paes de Almeida (2001, pp.180-182), conclui-se que o sócio-gerente ou administrador, em verdade, responde por ato ou omissão próprios, sem porém, que tal responsabilidade pessoal implique quebra do princípio da separação entre as pessoas físicas e a pessoa jurídica da sociedade. Desse modo, não se pode deixar de apontar que tal responsabilização deriva 
de atos dos diretores como pessoas naturais, portanto, não se tratando de desconsideração da personalidade jurídica.

\section{CONSIDERAÇÕES FINAIS}

A partir do momento em que as pessoas naturais se agrupam para centralizar seus esforços com o intuito de, por meio de entes coletivos, alcançar resultados positivos e vantagens, buscando a realização coletiva de seus interesses, o ordenamento jurídico lhes outorga personalidade. Esta personificação de entes abstratos torna possível a existência de uma autonomia, de modo que possam atuar independentemente das pessoas que fazem parte de sua formação, o que lhes autoriza uma ação mais proveitosa, segura e ágil, em face dessa estrutura. Assim, a pessoa jurídica surge como meio de suprir certas necessidades decorrentes das relações sociais.

Contudo, não obstante os inegáveis benefícios e vantagens derivados desse ente jurídico, este está passível de desvio de finalidade, má gestão, confusão patrimonial, abusos de direito, etc. Dessa forma, verificado o mau uso desse ente coletivo, utilizado de forma contrária ao direito, por atos danosos praticados pelas pessoas que o compõem, pode ser tornada sem efeito essa autonomia jurídica, sem que lhe seja determinada a sua extinção.

Ou seja, apesar de ter se apresentado como solução a diversas questões, a pessoa jurídica passou a ser utilizada indevidamente. Em decorrência disso, houve o nascimento, no direito alienígena, da doutrina da desconsideração da personalidade jurídica, como um meio de estabelecer limites à utilização de tal instituto, visto que prevê a possibilidade de as obrigações contraídas pela sociedade atinja o patrimônio de seus sócios, uma vez atendidos determinados requisitos.

Como visto, essa teoria foi acolhida pelo direito pátrio, de forma que se nota sua presença em diversos dispositivos legais, ainda que com algumas modificações. Quando se trata do processo falimentar e da sociedade falida, a Lei 11.101/05, a nova Lei de Falências, dispõe, em seus artigos 81 e 82, sobre a responsabilização dos sócios. Embora tais dispositivos apresentem a efetiva possibilidade de o patrimônio dos componentes da sociedade ser alcançado, não apresentam uma real aplicação da teoria da desconsideração da personalidade jurídica, em sua formulação original. Todavia, mais importante do que saber se determinado dispositivo representa ou não uma

(C) 2008. Departamento de Direito da UFSM. Todos os direitos reservados. 
hipótese em conformidade com a doutrina da desconsideração da personalidade jurídica é buscar, de acordo com a legislação vigente, a solução mais adequada para cada caso.

Sendo assim, imperioso ressaltar que a disregard doctrine é providência de caráter excepcional, aplicada sobre determinado caso concreto, desde que efetivamente comprovado o desvio de finalidade legal ou a ocorrência de confusão patrimonial, hipóteses exclusivas estas contempladas no texto do Código Civil. Logo, não se pode olvidar dos fundamentos que embasam a concessão de personalidade aos entes coletivos e, assim, simplesmente tornar sem efeito a figura da pessoa jurídica, a qual traz salutares e benéficos efeitos à sociedade. O emprego da desconsideração da personalidade jurídica, que representa uma salvaguarda dos interesses da sociedade contra o desvirtuamento da finalidade da pessoa jurídica pelos sócios, deve ser feita de forma cautelosa e precavida, caso contrário, abolir-se-á completamente o instituto da pessoa jurídica.

Noutras palavras, a desconsideração da personalidade jurídica não pode ser levada ao exagero, a ponto de subverter o instituto da pessoa jurídica, acabando por eliminar as extraordinárias contribuições trazidas pela personificação dos entes abstratos às relações sociais. Tão-somente nas hipóteses em que a fraude ou abuso de direito restem comprovados de maneira peremptória é autorizada a desconsideração, para atingir a pessoa do sócio, alcançando seu patrimônio, de modo a evitar iniqüidades.

\section{REFERÊNCIAS BIBLIOGRÁFICAS}

ALMEIDA, Amador Paes de. Execução de bens dos sócios: obrigações mercantis, tributárias, trabalhistas: da desconsideração da personalidade jurídica (doutrina e jurisprudência). São Paulo, SP: Saraiva, 2001.

COELHO, Fábio Ulhoa. Comentários à nova Lei de Falências e de recuperação de empresas (Lei n. 11.101, de 9-2-2005). 4. ed. São Paulo, SP: Saraiva, 2007.

Manual de direito comercial. 17. ed. rev. e atual. de acordo com a nova Lei de falências. São Paulo, SP: Saraiva, 2006.

FREITAS, Elizabeth Cristina Campos Martins de. Desconsideração da personalidade jurídica: análise à luz do código de defesa do consumidor e do novo código civil. São Paulo, SP: Atlas, 2002. 
DENARI, Zelmo... [et al.]. Código brasileiro de defesa do consumidor: comentado pelos autores do anteprojeto. 9. ed. rev., atual. e ampl. Rio de Janeiro, RJ: Forense Universitária, 2007.

NERY JR, Nelson; NERY, Rosa Maria de Andrade. Código Civil comentado. 4. ed. ver., atual. e ampl. São Paulo, SP: Revista dos Tribunais, 2006.

PINTO, Eduardo Viana. Desconsideração da personalidade jurídica no novo código civil. Porto Alegre, RS: Síntese, 2003.

REQUIÃO, Rubens. Curso de direito comercial. v. 1. 27. ed. rev. e atual. de acordo com a lei n. 11.101, de 9-2-2005 (nova lei de falências). São Paulo, SP: Saraiva, 2007.

Curso de direito comercial. v. 2. 25. ed. rev. e atual. de acordo com a lei n. 11.101, de 9-2-2005 (nova lei de falências). São Paulo, SP: Saraiva, 2007.

VENOSA, Sílvio de Salvo. Direito civil: parte geral. 5. ed. São Paulo, SP: Atlas, 2005. (Coleção direito civil; v. 1.) 